\title{
GEOGRAPHICALLY WEIGHTED LOGISTIC REGRESSION DENGAN FUNGSI KERNEL FIXED GAUSSIAN PADA KEMISKINAN JAWA TENGAH*
}

\author{
Wulandari ${ }^{1}$ \\ 1Badan Pusat Statistik (BPS) Kabupaten Wonosobo, Indonesia, wulanda@bps.go.id \\ Indonesian Journal of Statistics and Its Applications (eISSN:2599-0802) \\ Vol 2 No 2 (2018), 101 - 112
}

Copyright $@ 2018$ Wulandari. This is an open-access article distributed under the Creative Commons Attribution License, which permits unrestricted use, distribution, and reproduction in any medium, provided the original work is properly cited.

\begin{abstract}
Poverty alleviation is a problem faced by many countries in the world, included Indonesia. Poverty in Indonesia still relatively high. Poverty is one indicator of welfare. In general, the decline in poverty means that people's welfare increasing. Poverty is a multi-dimensional problem, which involves various microeconomic and macroeconomic factors, including the influence of the surrounding region. Modeling with geographically weighted regression (GWR) accommodates heterogeneous effects of independent variables on the dependent variable and produces a local parameter estimates. Central Java has the second highest poverty rate among provinces in Java. This study will model poverty in Central Java with a model that accommodates the influence of the surrounding region, named Geographically Weighted Logistic Regression (GWLR). Poverty modeling in Central Java with GWLR, in general, literacy rates (AMH), per capita GRDP, and Labor Force Participation Rate (TPAK) significantly affected poverty in Central Java with values that varied between districts / cities.
\end{abstract}

Keywords: poverty, binary response, geographically weighted logistic regression.

\section{Pendahuluan}

Kemiskinan merupakan masalah umum dan utama yang dihadapi oleh banyak negara di dunia, terutama negara-negara berkembang, termasuk Indonesia. Bahkan, pengentasan kemiskinan merupakan tujuan pertama dalam 19 tujuan pembangunan berkelanjutan (SDGs) yang disepakati negara-negara di dunia. Kemiskinan menjadi isu sentral karena indikator ini merupakan indikator yang sangat penting untuk melihat tingkat kesejahteraan masyarakat di suatu wilayah. Selain itu kemiskinan merupakan faktor pemicu banyak permasalahan sosial di masyarakat, contohnya kriminalitas (Prayetno, 2013).

\footnotetext{
${ }^{*}$ Received Nov 2018; Accepted Nov 2018; Published online on Nov 2018
} 
Kemiskinan di Indonesia masih tergolong tinggi. Sekitar 36 juta orang di kawasan ASEAN masih hidup di bawah garis kemiskinan internasional. Mayoritas dari total jumlah tersebut terdapat di Indonesia dan Filipina. Indonesia sendiri menyumbang sekitar 60 persen dari total jumlah tersebut (Kadir, Kompasiana).

Pada tahun 2017, Jawa Tengah merupakan provinsi dengan persen penduduk miskin kedua terbesar di Pulau Jawa dan terbesar ketiga belas di Indonesia. 12,23 persen penduduk Jawa Tengah dinyatakan miskin. Pengentasan kemiskinan di Jawa Tengah akan membawa dampak yang cukup berarti bagi kemiskinan Indonesia karena 13,22 persen penduduk Indonesia tinggal di Jawa Tengah (BPS).

Permasalahan kemiskinan merupakan masalah multidimensional yang melibatkan banyak aspek, mulai dari sosial, ekonomi, budaya, geografis, dll, sehingga dalam menganalisis kemiskinan perlu melibatkan aspek-aspek yang mungkin berpengaruh. Setyorini (2017) mengemukukan bahwa kemiskinan merupakan masalah yang tidak hanya dipengaruhi oleh nilai-nilai pada suatu wilayah, tetapi juga dipengaruhi oleh geografi, posisi suatu wilayah terhadap wilayah lain. Selain itu, faktor-faktor yang mempengaruhi kemiskinan, sangat mungkin memberikan pengaruh yang tidak sama antar daerah, sehingga untuk memodelkan kemiskinan, faktor-faktor tadi harus diperhitungkan.

Pemodelan dengan regresi global akan menghasilkan estimasi parameter yang bernilai sama untuk seluruh wilayah. Dalam regresi global diasumsikan bahwa pengaruh variabel-variabel independen terhadap variabel dependen bersifat homogen. Pada kenyataannya, kondisi sosial, budaya, geografis, dan ekonomi memberikan pengaruh yang tidak selalu sama terhadap kemiskinan di suatu wilayah, sehingga pemodelan dengan regresi global kurang tepat digunakan. Geographically Weighted Regression (GWR) adalah model regresi yang dikembangkan oleh Fotheringham et al. (2002). Ide dari model GWR adalah mengakomodir keberagaman pengaruh variabel dependent terhadap variabel independent. GWR merupakan pengembangan regresi global dengan menyertakan pengaruh suatu wilayah terhadap wilayah lain. Estimasi parameter yang dihasilkan oleh model GWR bersifat lokal pada masing-masing wilayah penelitian, sehingga setiap wilayah akan memiliki estimasi parameter masing-masing.

Variabel dependen dalam penelitian ini bersifat biner (yaitu miskin dan tidak miskin), sehingga membutuhkan analisis regresi untuk data biner. Regresi logistik umumnya digunakan untuk memodelkan data respon berbentuk biner. Karena ingin mengakomodir heterogenitas spasial, maka dalam penelitian ini akan dimodelkan kemiskinan di Jawa Tengah dengan menggunakan model Geographically Weighted Logistic Regression (GWLR).

Mengingat pentingnya pengentasan kemiskinan serta persen penduduk miskin yang masih tinggi di Jawa Tengah, serta kemiskinan dipengaruhi oleh faktor lokasi, maka dalam penelitian ini akan dimodelkan kemiskinan di Jawa Tengah dengan menggunakan Geographically Weighted Logistic Regression (GWLR). Penelitian ini diharapkan dapat menjadi bahan masukan dalam upaya pengentasan kemiskinan di kabupaten/kota Jawa Tengah serta menambah wawasan keilmuan. 


\section{Metodologi}

\subsection{Bahan dan Data}

Penelitian ini mencakup 35 kabupaten/kota di Jawa Tengah. Data yang digunakan adalah data tahun 2017. Semua data yang digunakan merupakan data sekunder yang didapat dari publikasi-publikasi Badan Pusat Statistik (2017 \& 2018). Variabel dependen, berupa data biner, adalah status kemiskinan suatu kabupaten/kota. Kabupaten/kota didefinisikan miskin $(=1)$ jika memiliki persen penduduk miskin lebih besar dari persen penduduk miskin Provinsi Jawa Tengah pada tahun 2017, dan didefinisikan sebagai tidak miskin $(=0)$ jika persen penduduk miskinnya kurang dari persen penduduk miskin Jawa Tengah. Persen penduduk miskin Jawa Tengah tahun 2017 adalah sebesar 12,23 persen. Variabel independen dalam penelitian ini ada sebanyak empat, yaitu Angka Melek Huruf (AMH) sebagai pendekatan dari sisi pendidikan, pertumbuhan ekonomi dan PDRB per kapita sebagai pendekatan dari sisi ekonomi, dan Tingkat Partisipasi Angkatan Kerja (TPAK) sebagai pendekatan dari sisi ketenagakerjaan.

Persen penduduk miskin, pertumbuhan ekonomi, dan PDRB per kapita didapat dari website jateng.bps.go.id. AMH didapat dari publikasi Statistik Pendidikan Provinsi Jawa Tengah 2017. TPAK didapat dari publikasi Profil Ketenagakerjaan Provinsi Jawa Tengah hasil Sakernas Agustus 2017. Pengolahan dilakukan dengan menggunakan software open source yaitu R dan GWR4.

\subsection{Metode Penelitian Regresi Logistik}

Regresi logistik adalah regresi yang paling umum digunakan untuk memodelkan variabel respon berupa data biner dengan satu atau beberapa variabel independen yang berbentuk kategorik dan atau kontinu (Agresti, 2002). Jika $n$ wilayah pengataman memiliki $p$ variabel penjelas yang ditunjukkan oleh vektor $X=$ $\left(x_{1}, x_{2}, \ldots, x_{p}\right)$ yang berpasangan dengan variabel respon $Y$ yang berbentuk biner, yaitu 1 atau 0 ( $y=1$ menyatakan sukses dan $y=0$ menyatakan gagal), maka peubah respon $Y$ mengikuti distribusi Bernoulli dengan parameter $\pi\left(\mathbf{x}_{i}\right)$. Fungsi distrubusi Bernoulli adalah:

$$
f\left(y_{i} \mid \pi\left(\mathbf{x}_{i}\right)\right)=\left[\pi\left(\mathbf{x}_{i}\right)\right]^{y_{i}}\left[1-\pi\left(\mathbf{x}_{i}\right)\right]^{1-y_{i}} \quad ; i=1,2, \ldots, n
$$

Bentuk umum model logistik adalah sebagai berikut:

$$
\pi\left(\mathbf{x}_{i}\right)=\frac{\exp \left(\beta_{0}+\beta_{1} x_{i 1}+\cdots+\beta_{p} x_{i p}\right)}{1+\exp \left(\beta_{0}+\beta_{1} x_{i 1}+\cdots+\beta_{p} x_{i p}\right)}=\frac{\exp \left(\boldsymbol{\beta}^{\prime} \boldsymbol{X}_{\boldsymbol{i}}\right)}{1-\exp \left(\boldsymbol{\beta}^{\prime} \boldsymbol{X}_{\boldsymbol{i}}\right)}
$$

dengan $\boldsymbol{\beta}^{\prime}=\left(\beta_{0}, \beta_{1}, \ldots, \beta_{p}\right)$ dan $\boldsymbol{X}_{\boldsymbol{i}}^{\prime}=\left(1, x_{i 1}, \ldots, x_{i p}\right)$

Model logistik adalah model nonlinier sehingga perlu dilakukan transformasi agar fungsi hubungan variabel penjelas dan respon menjadi linier. Bentuk tranformasi tersebut adalah: 


$$
g\left(\mathbf{x}_{i}\right)=\ln \left(\frac{\pi\left(\mathbf{x}_{i}\right)}{1-\pi\left(\mathbf{x}_{i}\right)}\right)=\beta_{0}+\beta_{1} x_{i 1}+\cdots+\beta_{p} x_{i p}=\boldsymbol{\beta}^{\prime} \boldsymbol{X}_{\boldsymbol{i}}
$$

Estimasi parameter model logistik dilakukan dengan menggunakan maximum likelihood estimation (MLE) yang bentuk akhirnya diselesaikan dengan menggunakan iterasi Newton-Raphson (Agresti, 2002).

\subsubsection{Multikolinieritas}

Dalam analisis regresi, salah satu asumsi yang harus terpenuhi adalah tidak adanya hubungan linier antar variabel penjelas (nomultikolinieritas). Multikolinieritas sempurna akan menyebabkan estimasi parameter menjadi tidak dapat ditemukan, sedangkan pada multikolinieritas tidak sempurna menyebabkan standard error model menjadi besar, yang berarti estimasi parameter yang dihasilkan menjadi tidak akurat (Gujarati, 2004). Salah satu deteksi multikolinieritas adalah dengan melihat nilai variance inflation factor (VIF). Nilai VIF pada koefisien regresi ke-j dirumuskan sebagai berikut:

$$
V I F_{j}=\frac{1}{1-R_{j}^{2}}
$$

dimana $R_{j}^{2}$ adalah koefisien determinasi yang diperoleh dengan meregresikan variabel $x_{j}$ dengan variabel penjelas $x_{\neq j}$ lainnya. Patokan umum yang digunakan adalah nilai VIF > 10 maka disimpulkan terjadi multikolinieritas.

\subsubsection{Heterogenitas Spasial}

Heterogenitas spasial diartikan sebagai suatu kondisi dimana suatu model regresi global tidak dapat menjelaskan hubungan antara variabel-variabel dalam model dikarenakan karakteristik antar wilayah pengamatan yang bervariasi secara spasial (Fotheringham et al. 2002). Uji heterogenitas yang dilakukan dalam penelitian ini adalah dengan menggunakan Uji Breusch-Pagan. Hipotesis yang digunakan adalah:

$$
\begin{aligned}
& H_{0}: \sigma_{1}{ }^{2}=\sigma_{2}{ }^{2}=\cdots=\sigma_{n}{ }^{2}=\sigma^{2} \\
& H_{1}: \text { minimal terdapat satu } \sigma_{i}{ }^{2} \neq \sigma
\end{aligned}
$$

Statistik uji Breusch-Pagan adalah:

$$
B P=\frac{1}{2} \mathbf{f}^{\mathrm{T}} \mathbf{Z}\left(\mathbf{Z}^{\mathrm{T}} \mathbf{Z}\right)^{-1} \mathbf{Z}^{\mathrm{T}} \mathbf{f} \sim \chi_{k}^{2}
$$

dimana $i=1,2, \ldots, n$ adalah banyak observasi; $\mathbf{f}=\left(f_{1} f_{2} \ldots f_{n}\right)^{\mathrm{T}}, f_{i}=\left(\frac{y_{i}-\hat{y}_{i}}{\sigma^{2}}-1\right) ; \boldsymbol{Z}$ adalah matrik berukuran $n \times k$ yang berisi varibel prediktor yang sudah distandarkan. Kriteria uji yang digunakan adalah tolak hipotesis nol jika nilai $B P>\chi_{k}^{2}$, dengan $k$ adalah banyaknya variabel prediktor.

\subsubsection{Geographically Weighted Regression (GWR)}

Geographically Weighted Regression (GWR) adalah pengembangan dari regresi global dengan menyertakan pengaruh wilayah sekitar terhadap suatu wilayah tertentu. Model ini dikembangkan oleh Fotheringham et al. (2002) untuk mengakomodir adanya heterogenitas spasial. Pemodelan dengan GWR menghasilkan estimasi parameter yang bersifat unik pada masing-masing wilayah penelitian. Pada model GWR, setiap 
wilayah memiliki titik koordinat spasial yang dilambangakan dengan $\left(u_{i}, v_{i}\right)$. Dalam penelitian ini, koordinat untuk masing-masing wilayah pengamatan adalah lokasi kantor bupati. Persamaan umum model GWR adalah untuk wilayah ke-i adalah sebagai berikut:

$$
y_{i}=\beta_{0}\left(u_{i}, v_{i}\right)+\sum_{j=1}^{k} \beta_{j}\left(u_{i}, v_{i}\right) x_{i j}+\varepsilon_{i} \quad ; i=1,2, \ldots, n
$$

Estimasi parameter model GWR di masing-masing lokasi dilakukan dengan menggunakan metode Weighted Least Square (WLS), yaitu dengan memberikan penimbang/pembobot. Pembobot ini akan berbeda nilainya untuk setiap wilayah. Rumus estimasi parameter model GWR pada wilayah ke- $i$ adalah:

$$
\widehat{\boldsymbol{\beta}}(i)=\left(\mathbf{X}^{\mathrm{T}} \mathbf{W}(i) \mathbf{X}\right)^{-1} \mathbf{X}^{\mathrm{T}} \mathbf{W}(i) \mathbf{y}
$$

dimana $\widehat{\boldsymbol{\beta}}(i)=\left(\hat{\beta}_{0}(i) \hat{\beta}_{1}(i) \hat{\beta}_{2}(i) \ldots \hat{\beta}_{k}(i)\right)^{T}$ adalah vektor koefisien regresi lokal wilayah $i ; \mathbf{W}(i)$ adalah matriks pembobot spasial wilayah ke-i, berukuran $n x n$ yaitu matriks diagonal dengan elemen pada diagonal utamanya merupakan pembobot geografis pada setiap data untuk lokasi pengamatan ke-i. $w_{i 1}$ adalah pembobot wilayah 1 terhadap wilayah ke- $i$, dst.

$$
\mathbf{W}(i)=\left[\begin{array}{cccc}
w_{i 1} & 0 & \ldots & 0 \\
0 & w_{i 2} & \ldots & 0 \\
\vdots & \vdots & \ddots & \vdots \\
0 & 0 & \ldots & w_{i n}
\end{array}\right]
$$

\subsubsection{Fungsi Pembobot Spasial}

Pembobot spasial menggambarkan letak data observasi/lokasi pengamatan satu dengan yang lainnya. Peran pembobot spasial dalam pemodelan spasial sangat penting. Pembahasan fungsi pembobot spasial melibatkan tiga hal, yaitu fungsi jarak, bandwidth, dan jenis fungsi kernel yang digunakan.

Fungsi jarak yang digunakan dalam penelitian ini adalah fungsi jarak Euclidean. Jarak Euclidean antara lokasi $\left(u_{i}, v_{i}\right)$ ke lokasi $\left(u_{h}, v_{h}\right)$ dirumuskan dengan $d_{i h}=$ $\sqrt{\left(u_{i}-u_{h}\right)^{2}+\left(v_{i}-v_{h}\right)^{2}}$. Terdapat banyak sekalian fungsi kernel, dan dalam penelitian ini fungsi kernel yang digunakan adalah fixed Gaussian. Rumus fungsi kernel fixed Gaussian adalah $w_{i h}\left(u_{i}, v_{i}\right)=\exp \left(-\frac{1}{2}\left(d_{i h} / b\right)^{2}\right)$ dimana $b$ adalah bandwidth yang digunakan dan $d_{i h}$ adalah jarak Euclidean.

Penaksiran parameter tidak sensitif terhadap kernel yang digunakan, tetapi sensitif terhadap nilai bandwidth yang digunakan (Fotheringham et al., 2002). Semakin besar bandwidth maka semakin mulus parameter yang artinya bias parameter menjadi besar karena model yang dihasilkan terlalu mulus dan bersifat sangat lokal. Semakin kecil bandwidth maka model yang dihasilkan semakin kasar artinya parameter yang dihasilkan semakin mendekati regresi global. Metode pemilihan bandwidth optimum yang digunakan dalam penelitian ini adalah dengan cross validation (CV). 


$$
C V=\sum_{i=1}^{n}\left[y_{i}-\hat{y}_{\neq i}(b)\right]^{2}
$$

dimana $\hat{y}_{\neq i}(b)$ adalah nilai taksiran $y_{i}$ dengan menggunakan bandwidth $\mathrm{b}$, dimana pengamatan di lokasi ke- $i$ tidak dimasukkan dalam perhitungan, yaitu dengan membuat bobot lokasi ke-i bernilai nol. Bandwidth optimum diperoleh jika nilai CV yang dihasilkan bernilai minimum (Fotheringham et al., 2002).

\subsubsection{Geographically Weighted Logistic Regression (GWLR)}

GWLR adalah pemodelan regresi yang dikembangkan oleh Atkinson et al. (2003) yang mengkomidir heterogenitas spasial pada variabel respon berupa data biner. Bentuk umum model GWLR wilayah ke- $i$ adalah:

$$
\pi\left(\mathbf{x}_{i}\right)=\frac{\exp \left(\sum_{k=0}^{p} \beta_{k}\left(u_{i}, v_{i}\right) x_{i k}\right)}{1+\exp \left(\sum_{k=0}^{p} \beta_{k}\left(u_{i}, v_{i}\right) x_{i k}\right)}=\frac{\exp \left(\boldsymbol{\beta}\left(u_{i}, v_{i}\right)^{\prime} X_{i}\right)}{1-\exp \left(\boldsymbol{\beta}\left(u_{i}, v_{i}\right)^{\prime} X_{i}\right)}
$$

Sedangkan bentuk umum model GWLR wilayah ke- $i$ setelah dilakukan transformasi adalah:

$$
g\left(\mathbf{x}_{i}\right)=\ln \left(\frac{\pi\left(\mathbf{x}_{i}\right)}{1-\pi\left(\mathbf{x}_{i}\right)}\right)=\boldsymbol{\beta}\left(u_{i}, v_{i}\right)^{\prime} \boldsymbol{X}_{\boldsymbol{i}}
$$

Estimasi parameter GWLR di setiap lokasi dilakukan dengan MLE, yang nanti penyelesaian akhirnya dihitung dengan iterasi Newton-Raphson. Iterasi akan berhenti jika didapat estimasi parameter yang konvergen. Estimasi awal parameter $\widehat{\boldsymbol{\beta}}\left(u_{i}, v_{i}\right)$ adalah menggunakan nilai estimasi parameter model logistik (global).

\subsubsection{Pengujian Parameter Model GWLR}

Pengujian parameter model GWLR secara serentak dengan hipotesis sebagai berikut:

$$
\begin{aligned}
& H_{0}=\beta_{1}\left(u_{i}, v_{i}\right)=\beta_{2}\left(u_{i}, v_{i}\right)=\cdots=\beta_{P}\left(u_{i}, v_{i}\right)=0 \\
& H_{1}=\text { minimal terdapat satu } \beta_{k}\left(u_{i}, v_{i}\right) \neq 0
\end{aligned} \quad k=1,2, \ldots, p
$$

Statistik uji yang digunakan adalah statistik $Z$ yang diperoleh dengan formulasi $G^{2}=$ $-2 \ln \left(\frac{L_{o}}{L_{1}}\right)$ dengan kriteria tolak Ho jika $G^{2}>\chi_{(\alpha, p)}^{2}$

Pengujian parameter model GWLR secara parsial dengan hipotesis sebagai berikut:

$$
H_{0}=\beta_{k}\left(u_{i}, v_{i}\right)=0
$$$$
H_{1}=\beta_{k}\left(u_{i}, v_{i}\right) \neq 0
$$

$$
k=1,2, \ldots, p
$$

Statistik uji yang digunakan adalah statistik uji $Z$ yang diperoleh dengan formulasi $Z=\frac{\widehat{\beta}_{k}\left(u_{i}, v_{i}\right)}{\operatorname{se}\left(\widehat{\beta}_{k}\left(u_{i}, v_{i}\right)\right)}$ dengan kriteria tolak Ho jika $|Z|>Z_{\alpha / 2}$

Metodologi yang digunakan dalam kajian ini diringkas dan disajikan dalam Gambar 1. 


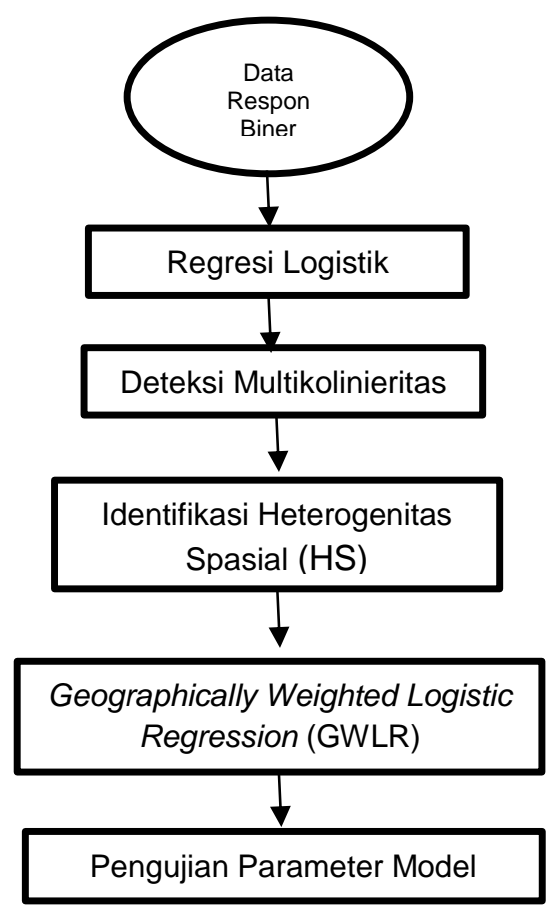

Gambar 1: Flowchart Metode Penelitian.

\section{Hasil dan Pembahasan}

\subsection{Deskriptif Kemiskinan di Jawa Tengah}

Provinsi Jawa Tengah terdiri dari 29 kabupaten dan 6 kota. Persen penduduk miskin Provinsi Jawa Tengah pada tahun 2017 adalah sebanyak 4,45 juta orang atau 13,01 persen dari total penduduk miskin di Indonesia.

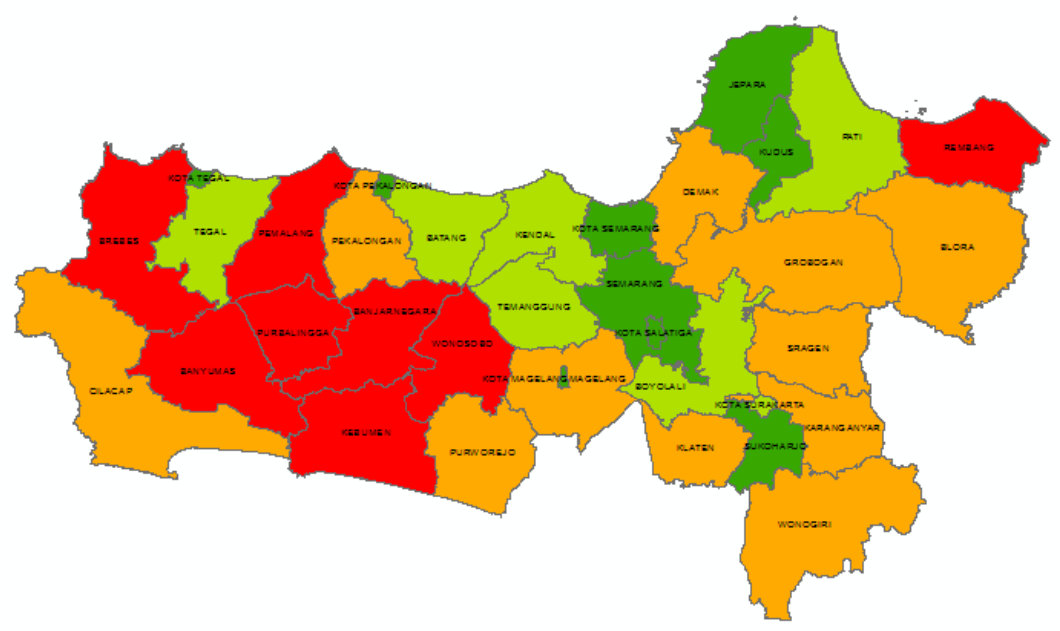

Gambar 2: Persen Penduduk Miskin Kabupaten/Kota di Jawa Tengah tahun 2017.

Dari Gambar 2 dapat dilihat terdapat variasi yang cukup besar dari persen penduduk miskin. Kabupaten/kota yang memiliki persen penduduk miskin yang cukup 
tinggi berada di bagian barat Jawa Tengah dan cenderung membentuk klaster, yaitu wilayah yang persen penduduk miskinnya tinggi wilayah sekitarnya juga persen penduduk miskinnya tinggi. Hal yang sama juga terjadi untuk wilayah-wilayah yang memiliki persen penduduk miskin yang rendah, umumnya wilayah sekitar juga persen penduduknya cenderung rendah. Terdapat beberapa outlier yaitu Kota Tegal, Kabupaten Tegal, dan Kabupaten Rembang. Pola persen penduduk miskin yang cenderung membentuk klaster dapat menjadi salah satu informasi yang penting ketika pemerintah provinsi ingin mengeluarkan kebijakan berkenaan dengan penurunan angka kemiskinan.

\subsection{Pemodelan Kemiskinan dengan Regresi Logistik}

Pemodelan pertama terhadap data kemiskinan adalah dengan regresi logistik. Selanjutkan akan dilihat multikolinieritas dan heterogenitas dari pemodelan dengan regresi logistik. Berikut adalah hasil dari pemodelan dengan regresi logistik.

Tabel 1: Nilai Estimasi Parameter Regresi Logistik.

\begin{tabular}{lcc}
\hline \multicolumn{1}{c}{ Variabel } & $\begin{array}{c}\text { Estimasi } \\
\text { Parameter }\end{array}$ & Signifikansi \\
\hline Intersep & 90.2459 & 0.0167 \\
Angka Melek Huruf $\left(\mathrm{X}_{1}\right)$ & -0.9976 & 0.1271 \\
Pertumbuhan Ekonomi $\left(\mathrm{X}_{2}\right)$ & -0.0948 & 0.0723 \\
PDRB per Kapita $\left(\mathrm{X}_{3}\right)$ & -0.6198 & 0.0428 \\
Tingkat Partisipasi Angkatan Kerja $\left(\mathrm{X}_{4}\right)$ & -0.3300 & 0.0806 \\
\hline
\end{tabular}

Berdasarkan Tabel 1 dapat dilihat bahwa dari empat variabel penjelas, 3 variabel yaitu pertumbuhan ekonomi, PDRB per Kapita, dan TPAK signifikan mempengaruhi kemiskinan di Jawa Tengah. Sedangkan AMH tidak signifikan mempengaruhi kemiskinan.

\subsection{Pengecekan Asumsi Multikolinieritas}

Nilai VIF keempat variabel penjelas dalam model regresi logistik, yang dihitung dengan menggunakan rumus (4) disajikan dalam Tabel 2.

Tabel 2: Nilai VIF Variabel-variabel Penjelas Model Regresi Logistik.

\begin{tabular}{ccccc}
\hline Variabel & $\mathbf{X}_{1}$ & $\mathbf{X}_{2}$ & $\mathbf{X}_{3}$ & $\mathbf{X}_{4}$ \\
\hline VIF & 1.4113 & 1.5128 & 1.1787 & 1.2783 \\
\hline
\end{tabular}

Keempat variabel bebas memiliki nilai VIF kurang dari 10 sehingga dapat disimpulkan tidak terdapat multikolinieritas antar variabel penjelas yang digunakan dalam model. 


\subsection{Pengecekan Asumsi Heteroskedas}

Deteksi heterogenitas dilakukan dengan menggunakan Breusch-Pagan Test (BPtest). Dengan menggunakan formulasi seperti pada rumus (5) didapat nilai BP-test adalah sebesar 8.6276. Nilai BP-test tersebut memiliki $p$-value 0.0711 , sehingga pada alpha 0,10 dapat disimpulkan terjadi heterogenitas dalam varians erromya.

\subsection{Pemodelan Kemiskinan dengan Geographically Weighted Logistic Regression (GWLR)}

Sebelum melakukan pemodelan dengan GWLR, pertama dicari terlebih dahulu bandwidth optimum yang akan digunakan. Dengan menggunakan fungsi fixed Gaussian kernel dan metode CV didapat nilai bandwidth optimum adalah sebesar 2,553434 . Selanjutnya nilai bandwidth tersebut digunakan untuk menghitung matrik pembobot spasial $(\mathbf{W})$ sehingga didapat matrik pembobot spasial berukuran $35 \times 35$. Berikut adalah summary dari estimasi parameter model GWLR yang disajikan pada Tabel 3.

Tabel 3: Summary Nilai Estimasi Parameter Model GWLR.

\begin{tabular}{lccc}
\hline \multirow{2}{*}{ Variabel } & \multicolumn{3}{c}{$\hat{\beta}$} \\
\cline { 2 - 4 } & Min & Median & Max \\
\hline Intersep & 89,82 & 92,00 & 93,82 \\
Angka Melek Huruf $\left(X_{1}\right)$ & $-0,64$ & $-0,63$ & $-0,62$ \\
Pertumbuhan Ekonomi $\left(X_{2}\right)$ & $-1,12$ & $-1,03$ & $-0,89$ \\
PDRB per Kapita $\left(X_{3}\right)$ & $-0,11$ & $-0,10$ & $-0,09$ \\
Tingkat Partisipasi Angkatan Kerja $\left(X_{4}\right)$ & $-0,37$ & $-0,34$ & $-0,31$ \\
\hline
\end{tabular}

Dari Tabel 3 dapat dilihat bahwa nilai intersep cukup bervariasi, dengan nilai minimum 89,92 dan nilai maksimum 93,82. Begitu juga untuk variabel pertumbuhan ekonomi dan partisipasi angkatan kerja. Sedangkan untuk variabel AMH dan PDRB per kapita variasi nilainya tidak begitu jauh. Pengaruh variabel AMH bernilai negatif di seluruh kabupaten/kota. Artinya peningkatan terhadap $\mathrm{AMH}$, yang berarti semakin baik capaian pendidikan di suatu wilayah, akan menurunkan angka kemiskinan. Nilai estimasi parameter $\mathrm{AMH}$ adalah $-0,62$ hingga $-0,64$ artinya kenaikan $1 \% \mathrm{AMH}$ akan mengurangi angka kemiskinan sebesar 0,62 hingga 0,64 kali. Pengaruh variabel pertumbuhan ekonomi bernilai negatif di seluruh kabupaten/kota. Artinya peningkatan terhadap pertumbuhan ekonomi akan menurunkan angka kemiskinan. Nilai estimasi parameter ini adalah $-0,89$ hingga $-1,12$ artinya kenaikan $1 \%$ pertumbuhan ekonomi akan mengurangi angka kemiskinan sebesar 0,89 hingga 1,12 kali. Pengaruh variabel PDRB per kapita bernilai negatif di seluruh kabupaten/kota. Artinya peningkatan terhadap PDRB per kapita, yang berarti semakin tinggi pendapatan masyarakat, akan menurunkan angka kemiskinan. Nilai estimasi parameter PDRB per kapita adalah 0,09 hingga $-0,11$ artinya kenaikan $1 \%$ PDRB per kapita akan mengurangi angka kemiskinan sebesar 0,09 hingga 0,11 kali. Pengaruh variabel TPAK bernilai negatif di seluruh kabupaten/kota. Artinya semakin banyak orang yang bekerja akan 
menurunkan angka kemiskinan. Nilai estimasi parameter ini adalah -0,31 hingga 0,37 artinya kenaikan $1 \%$ pertumbuhan ekonomi akan mengurangi angka kemiskinan sebesar 0,31 hingga 0,37 kali.

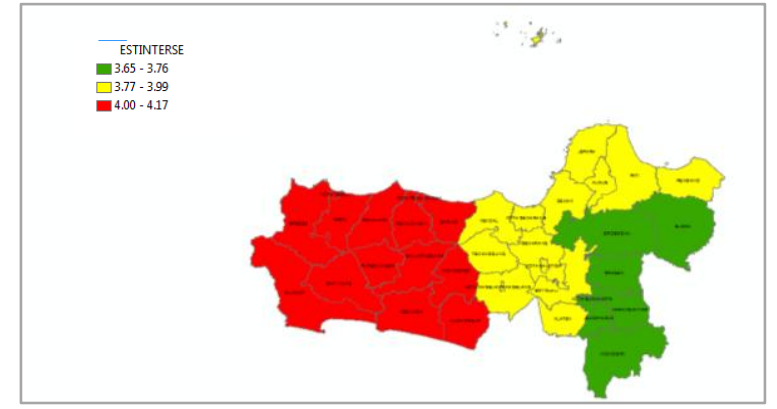

Gambar 3: Peta Nilai Estimasi Intersep

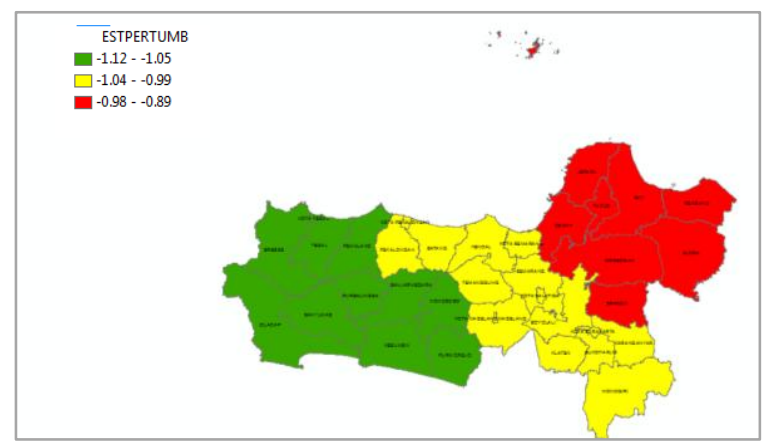

Gambar 5: Peta Nilai Estimasi Pertumbuhan Ekonomi

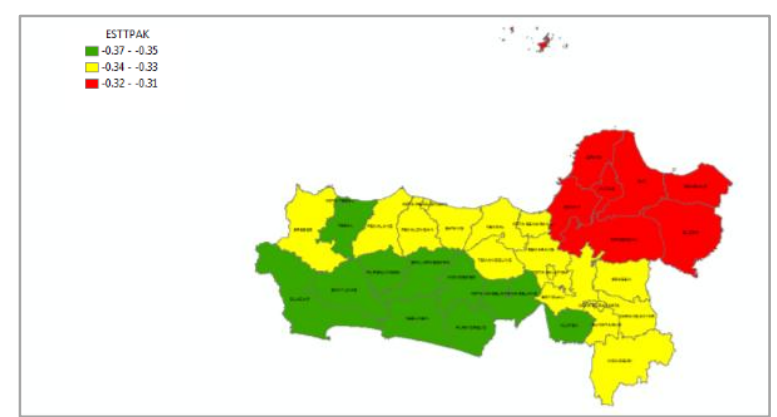

Gambar 7: Peta Nilai Estimasi TPAK

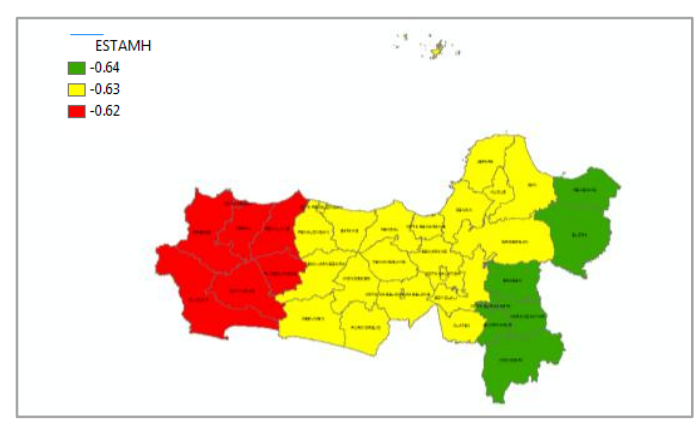

Gambar 4: Peta Nilai Estimasi AMH

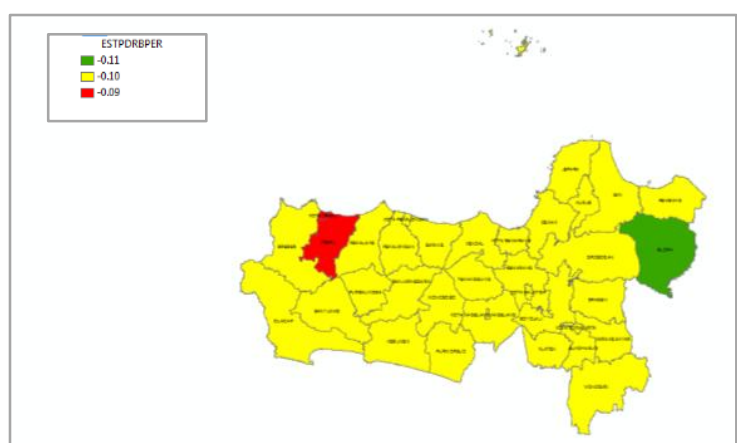

Gambar 6: Peta Nilai Estimasi PDRB per Kapita

Dari Gambar $3-7$ peta estimasi nilai parameter di atas, ternyata antar variabel penjelas memiliki sebaran yang berbeda. Artinya wilayah-wilayah yang suatu variabel memiliki pengaruh lebih besar, yaitu yang berwarna hijau, maka kebijakan penurunan kemiskinan bisa dilakukan intervensi melalui variabel tersebut. Sebagai contoh variabel $\mathrm{AMH}$, yaitu 6 kabupaten/kota di bagian timur, yang memiliki warna hijau, berarti penurunan kemiskinan dapat dilakukan melalui peningkatan $\mathrm{AMH}$. Begitu juga dengan ketiga variabel penjelas yang lain. 


\subsection{Signifikansi Parameter Model}

Secara umum, dari lima nilai estimasi parameter model GWLR, intersep dan AMH signifikan pada alpha 0.05 di seluruh kabupaten/kota di Jawa Tengah. Variabel PDRB per Kapita dan TPAK signifikan mempengaruhi kemiskinan pada 0,1 di seluruh kabupaten/kota di Jawa Tengah. Pertumbuhan ekonomi signifikan mempengaruhi kemiskinan pada 0,1 hanya di satu kabupaten yaitu Kabupaten Cilacap, sedangkan di 34 kabupaten/kota yang lain tidak signifikan mempengaruhi kemiskinan.

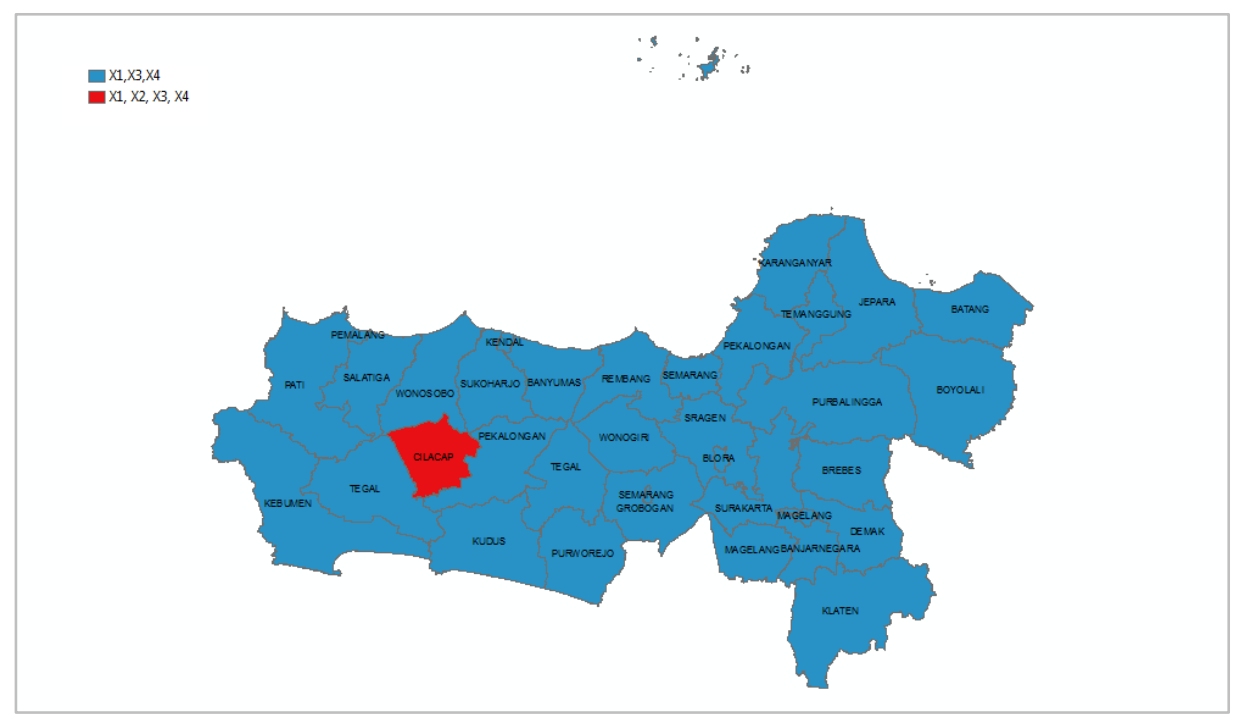

Gambar 8: Signifikansi Gabungan Parameter Model pada Taraf Signifikansi 0,10.

Dari Gambar 8, kabupaten/kota yang berwarna biru berarti variabel AMH, PDRB per kapita, dan TPAk signifikan mempengaruhi kemiskinan pada taraf 0,10, sedangkan kabupaten yang berwarna merah, yaitu Cilacap, seluruh variabel penelitian signifikan mempengaruhi kemiskinan.

\section{Simpulan dan Saran}

Berdasarkan hasil penelitian, pemodelan dengan GWLR menghasilkan nilai estimasi parameter yang beragam antar kabupaten/kota. Variasi pengaruh pertumbuhan ekonomi dan TPAK terhadap kemiskinan cukup bervariasi antar kabupaten/kota dan cenderung membentuk klaster. Pengaruh AMH dan PDRB per kapita terhadap kemiskinan tidak begitu bervariasi antar kabupaten/kota walaupun tetap ada kecenderungan pembentukan klaster. Dari empat variabel penelitian terdapat 3 variabel yang signifikan mempengaruhi kemiskinan di Jawa Tengah di seluruh wilayah kabupaten/kota, baik pada tingkat signifikansi 0,05 atau 0,1. Tiga variabel tersebut adalah Angka Melek Huruf, Pendapatan per Kapita, dan Tingkat Partisipasi Angkatan Kerja. Satu variabel, yaitu pertumbuhan ekonomi tidak signifikan mempengaruhi kemiskinan di seluruh wilayah di Jawa Tengah, kecuali Cilacap.

Kebijakan penurunan kemiskinan dapat dilakukan berbeda-beda antar wilayah, mempertimbangkan besar kecilnya pengaruh variabel penjelas di setiap kabupaten/kota. Saran untuk penelitian selanjutnya, bisa diterapkan pemodelan dengan mixed GWLR melihat ada beberapa variabel yang variasi pengaruh terhadap kemiskinan antar kabupaten/kota tidak terlalu besar, sehingga variabel tersebut dapat dijadikan parameter global. Sedangkan untuk variabel yang variasi pengaruhnya cukup besar dijadikan parameter lokal. 


\section{Daftar Pustaka}

Agresti, A. (2002). An introduction to categorical data analysis. Wiley.

Atkinson, P. M., German, S. E., Sear, D. A., \& Clark, M. J. (2003). Exploring the relations between riverbank erosion and geomorphological controls using geographically weighted logistic regression. Geographical Analysis, 35(1), 58-82.

Badan Pusat Statistik. (2017). Statistik Pendidikan Provinsi Jawa Tengah 2017. Semarang: Badan Pusat Statistik

Badan Pusat Statistik. (2018). Profil Ketenagakerjaan Provinsi Jawa Tengah Hasil Sakernas Agustus 2017. Semarang: Badan Pusat Statistik

Fotheringham, A.S., Brunsdon C., Charton, M. (2002). Geographically Weighted Regression, The Analysis of Spatially Varying Relationships. Canada: John Wiley \& Sons

Gujarati, D. N. (2004). Basic econometrics. Tata McGraw-Hill Education.

Prayetno, P. (2013). Kausalitas Kemiskinan terhadap Perbuatan Kriminal (Pencurian). Media Komunikasi FIS, 12(1).

Setiyorini, A. (2017). Pemodelan Tingkat Kemiskinan Pulan Jawa dengan Metode Geographically Weighted Lasso. Tesis: Universitas Padjajaran 